\title{
Editorials
}

\section{Peer review policies and the Canadian Journal of Anesthesia: an update for authors and readers}

\author{
Donald R. Miller MD FRCPC, ${ }^{\star}$ François Donati MD FRCPC $†$
}

$\mathrm{T}$ HE well established process of editorial peer review determines which manuscripts submitted to medical journals are accepted for publication and, secondarily, improves the quality of published articles. While the peer review process dates back more than two centuries, the practice of editorial peer review only developed in the latter half of the $20^{\text {th }}$ century. ${ }^{1}$ This process evolved independent of grant-driven peer review to address the demand for expertise and objectivity in the increasingly specialized world of biomedical publication. While still relatively new and developing, ${ }^{2}$ great strides have taken place over the last two decades in scientifically evaluating and guiding the peer review process through research, with a key role played by organizations such as the Council of Science Editors (www.councilscienceeditors.org), the World Association of Medical Editors (WAME) Www.wame. org) and the International Committee of Medical Journal Editors (ICMJE) (www.icmje.org).

Understanding the basic elements of peer review should give readers a better appreciation of factors involved in the selection and presentation of the articles they read. Authors should have an understanding of peer review policies to better appreciate the editorial decision-making process and thereby improve their manuscripts prior to submission. The principles for peer review within a journal should be fair, rigorous, and transparent. To this end, a journal should establish and publish its own unique policies and procedures, including regular updates. ${ }^{3}$ This editorial elaborates on the Journal's current peer review process and policies, and highlights several recent enhancements. Peer review policies are just one aspect of journal editorial policies, many of which are beyond the scope of this editorial.

\section{Manuscript screening}

Each submission to the Journal is first screened for its covering letter, signed by all authors, which must indicate that the material is original, that it has not been published previously, either in whole or in part, and that the manuscript is not under consideration for publication elsewhere. The importance of the covering letter has been highlighted recently. ${ }^{4}$ Each electronically submitted manuscript is then converted into a portable document file (PDF), and authors are requested to verify that its contents (text, figures, tables) are complete and accurate as submitted, before the manuscript enters the Journal's peer review system. In view of the recent ICMJE policy statement on mandatory registration of randomized controlled trials, ${ }^{5}$ we now encourage protocol registration within a recognized public registry for all phase 3 clinical trials (those which evaluate clinical efficacy or adverse effects), and inclusion of the trial registration number on the manuscript. While protocol registration is encouraged, the Journal has not yet mandated such registration as a condition of publication.

In the next step of manuscript processing, the Editor or Associate Editor reviews each manuscript for documented ethics approval, and evaluates the manuscript's compliance with content and format requirements as described in the Instructions for Authors published in the January and July issues and posted at http:/ www.cja-jca.org. Manuscripts meeting these initial conditions are then prioritized for potential peer review. Manuscript prioritization has become necessary, as the Canadian Journal of Anesthesia, like many other journals, has experienced an increasing volume of submissions in recent years, yet has a limited pool of experts to undertake the reviews. Poorly written manuscripts, and those with clear methodological

\footnotetext{
CAN J ANESTH $2007 / 54: 1 /$ pp 1-8
}

From the Editorial Office of the Canadian Journal of Anesthesia* $\dagger$ and the Departments of Anesthesiology, The University of Ottawa, * Ottawa, Ontario; and the University of Montreal, $\uparrow$ Montreal, Quebec, Canada.

Address correspondence to: Dr. Donald R. Miller, Editor-in-Chief, Canadian Journal of Anesthesia, Department of Anesthesia, The Ottawa Hospital, General Campus, Room 2600, 501 Smyth Road, Ottawa, Ontario K1H 8L6, Canada. Phone: 450-477-7607; Fax: 450-477-8472; E-mail: cja_office@cas.ca 
or reporting deficiencies are unlikely to be sent for peer review. Manuscripts to be reviewed are considered under the categories of: 1) reports of original investigations, 2) review articles/brief reviews, 3) case reports/case series, and 4) special articles. Each manuscript is assigned to two reviewers.

\section{Reviewer selection}

Reports of original investigations are usually assigned to one editorial board member and one guest reviewer. For each manuscript, these individuals are selected from one of the 17 Canadian University Departments of Anesthesiology or international institutions, and are chosen according to their expertise in research methodology and the content area of submission. While editorial board and guest reviewers are usually chosen by the Editors, we occasionally invite authornominated reviewers when the content area is very specialized and the number of experts is limited. While author-nominated reviewers may bias their recommendations in favour of acceptance, the quality of author-nominated reviewer's assessments, as verified by a validated Review Quality Instrument, ${ }^{6}$ is no different than editor-identified reviewers. When guest reviewers are invited to undertake a review, they are first asked to declare any competing interests before receiving a PDF file of the manuscript. The Journal transitioned from paper copy to an electronic manuscript submission and peer review process in 2005 , so instructions for completing reviews and an electronic assessment form accompany the manuscript file as email attachments. We request that reviewers complete and return their assessments within three weeks.

A recent incentive provided to our Canadian guest reviewers is the ability to claim continuing medical education (CME) credits under the Maintenance of Competence Program of the Royal College of Physicians and Surgeons of Canada. To assist with this process, instructions for documenting the credit hours related to a review are also included with the Reviewer's Form. E-mail based communication with all reviewers facilitates the efficiency of reviews, in our ongoing effort to decrease the peer review lag time (the time from an original submission to a decision). The Journat's mean peer review lag time is now less than six weeks. Longer review times may occur because of infrequent late assessments or unusual manuscript complexity.

\section{Blinding policies}

As with the majority of journals in the specialty, manuscript reviews are conducted in a single-blinded manner, in that the reviewers are aware of the authors and their affiliations, but copies of the 'Comments for the Authors' which are attached to the decision letter remain anonymous. On a separate form entitled 'Comments to the Board' not sent to the authors, the reviewers complete a checklist and make recommendations to the editorial board for acceptance, possible acceptance pending an appropriate revision, or rejection. Several years ago, the Journal attempted to minimize reviewer bias by using a double-blind review system which excluded authors' names and affiliations from manuscripts sent for review. This process was abandoned, however, as some authors were recognizable, either through self-citation, or reporting of certain trials or experiments from models unique to a given centre or laboratory.

Blinding reviewers to authors' identities might not improve review quality or recommendations regarding publication. ${ }^{7}$ Consequently, some anesthesia journals, for example the web-based BMC Anesthesiology (www.biomedcentral.com), use an 'open' system of peer review, where readers may view the 'pre-publication history' for each manuscript published including named reviewers' critiques, and authors' responses. This approach to review is open, yet reviewers might be less critical if commenting on the work of colleagues. Moreover, a recent study comparing open vs singleblinded review models suggests that open peer review might cause some experts to decline the work of reviewing manuscripts. ${ }^{8}$ Since one of the great challenges of any peer review system is maintaining a cohort of willing expert reviewers, at present we will continue to follow the tradition of a single-blinded system of peer review.

\section{The Decision}

When board member and guest reviewer assessments return to the Editorial Office, the Editor or the Associate Editor (in particular, when the Editor has a competing interest on a given manuscript) reviews the entire file and makes a final decision regarding acceptance. Manuscripts identified through the review process as having sufficient novelty, scientific validity and overall importance, while meeting ethical norms ${ }^{9}$ will most likely be accepted. When considering reports of randomized controlled trials or basic science research, we recognize that there are no 'perfect studies', so the importance of the primary question is carefully considered in conjunction with the rigour of the trial design and quality of scientific reporting. Reviews and case reports/case series must have educational value, appropriate novelty, and reflect the current state of knowledge on a particular subject.

During the review process, complex methodological, statistical or ethical issues may arise. When these issues 
surpass the reviewer's or Editor's areas of expertise, additional consultation may occur with the Journal's Consultant Ethicist, Consultant Epidemiologist, or a guest statistician. These additional expert opinions also weigh in the final decision regarding acceptance, and the additional comments are shared with the authors.

Very few $(<3 \%)$ manuscripts are accepted as submitted, and final acceptance is usually contingent upon receipt of an appropriate revision in response to the reviewers' and Editor's combined comments. The Journal does not set a target acceptance rate, and the actual acceptance rate (28\% in 2005) varies from year to year depending on the manuscripts received. When the required revisions are minor, and the authors have responded adequately, the decision to accept is made by the Editor, without sending the manuscript again through the review process. When the required revisions are major, however, a decision on potential acceptance must await re-examination of the revised manuscript, and may involve additional peer re-assessment, usually with the same reviewers who critiqued the initial version. This is particularly the case when it is unclear if problems relate to reporting deficiencies or methodological deficiencies. While reporting deficiencies might be corrected, methodological deficiencies likely cannot. Consequently, the authors may be advised that we are unable to make a decision prior to resubmission and re-assessment.

\section{Editorials}

The Journal publishes an average of two editorials per issue, and a recent readership survey indicated their popularity. During the review process, reviewers are invited to recommend manuscripts which potentially warrant an editorial, and may suggest editorial authors. Editorials are published at the invitation of the Editor. Most editorials are related to an article within a given issue, and provide a platform to expand the contextual background of the article, with a combination of appropriate literature citation and personal expert opinion. 'Free-standing' editorials on topics of special interest such as ethical issues, trial methodology and reporting, and journal policy are also published. Editorials are reviewed by the Editor-in-Chief, and are published with the authors' names, affiliations and statements of competing interests. Editorials do not reflect the policies of the Journals owner, the Canadian Anesthesiologists' Society.

\section{Letters to the editor}

We welcome submissions in consideration for publication in our Correspondence section. As with other manuscripts, letters to the editor must contain origi- nal material neither previously published, nor under consideration for publication elsewhere. The Editor[s] decide which letters are published, in consultation with the editorial board as required. All letters are subject to editing and abridgement. As letters to the editor serve an important role in "post-publication peer review," we invite authors of previously published articles to reply to correspondence regarding their work. Such replies, pending acceptance, are published along with the original letter.

\section{Language policies as they relate to peer review}

Reflecting Canada's official bilingual language policy, manuscripts may be submitted to the Journal in either English or French. Many French-speaking authors elect to write articles in English, so the results of their investigations are more likely to be accessible to potential readers. English has become, by far, the most widely used language of scientific communication, and is therefore attractive for authors even if their mother tongue is another language. However, abstracts are available in English in the Journal and through the most popular data bases, such as PubMed, Medline and Embase, so that the contents of a French-language article are unlikely to be missed. Thus, authors are welcome to submit manuscripts in French, especially if they feel that the message will be conveyed more clearly if written in that language.

The review process is the same for French and English manuscripts, with the same requirements for originality and validity. In particular, the Journal will not normally accept a study that replicates another published in English previously, just because the manuscript is in another language. The proportion of accepted submissions turns out to be approximately the same in both languages. Both English- and French-speaking authors are encouraged to provide a translation of their abstracts into the alternate language, if they feel they are sufficiently fluent. The Journal provides a translation in either direction for those who cannot, or prefer not to, submit a translation. Translating French abstracts into English allows the English version to appear in electronic data bases. French versions are not part of these data bases, but are appreciated by the large number of French-speaking subscribers to the Journal. The full text of editorials and some special articles appear in both languages. This policy has been adopted because of the high profile of the articles in question.

\section{Declaration of conflicts of interest}

Finally, in addressing the integrity of the peer review process, we acknowledge that both the reviewers and 
editors might have conflicts of interest. Conflicts of interest are "a set of conditions in which professional judgment concerning a primary interest (such as patient welfare or the validity of research) can be influenced by a secondary interest (such as financial gain)". ${ }^{10}$ Many journals now publish both authors' and reviewers' conflicts of interest. While commercial interests may be overt in the peer review process, editorial conflicts of interest may operate at more subtle levels. For example, an editor may develop a bias for or against a certain group of authors; or an author's work may compete with an editor's work in the same field. ${ }^{11}$ As several other journals in the specialty have recently done, the Canadian Journal of Anesthesia now declares on the Journal's website the affiliations and conflicts of interest, both financial and non-financial, of the editorial board members and Editors. Board Members must also declare real or perceived competing interests for each manuscript they review, and the Editor-in-Chief defers to the Associate Editor-in-Chief for decisions regarding any manuscript originating from his University Department. We acknowledge the need for greater transparency for all journals, and the need for editorial accountability for decisions regarding acceptance. The effectiveness of policies addressing this important issue requires further evaluation.

\section{Conclusions}

Editorial peer review is a very important process that determines which manuscripts are published in peer reviewed journals, while concurrently having a major influence on the quality of published articles. While the science of peer review continues to evolve, the process should be transparent, and should be of interest to all those who contribute to, and those who read the medical literature. The published scientific literature advances the practice of medicine. In this context, we are pleased to update contributing authors and our readership on the Journat's peer review policies.
La politique d'évaluation par des pairs du Journal Canadien d'Anesthésie : une mise à jour destinée aux auteurs et aux lecteurs

L'évaluation de manuscrits par des pairs est un processus bien établi visant à déterminer quels manuscrits sont acceptés pour la publication lors de leur soumission à des revues médicales; de plus, ce processus améliore la qualité des articles publiés. Bien que le processus d'évaluation par des pairs remonte à plus de deux siècles, cette pratique ne s'est développée que dans la seconde moitié du $20^{\text {ème }}$ siècle. ${ }^{1}$ Ce processus a évolué indépendamment du système d'évaluation par des pairs pour l'attribution de subventions afin de répondre aux exigences d'expertise et d'objectivité dans le monde de plus en plus spécialisé de la publication biomédicale. Bien que cette pratique soit encore relativement récente et en développement, ${ }^{2}$ de grands progrès ont eu lieu ces vingt dernières années dans l'évaluation scientifique et l'orientation du processus d'évaluation par des pairs grâce à la recherche; des organismes tels le Council of Science Editors (www. councilscienceeditors.org), la World Association of Medical Editors (WAME) (www.wame.org) ainsi que le International Committee of Medical Journal Editors (ICMJE) (www.icmje.org) ont joué un rôle majeur dans cette évolution.

La compréhension des éléments de base de l'évaluation par des pairs permettra aux lecteurs une appréciation plus juste des facteurs qui entrent en ligne de compte dans la sélection et la présentation des articles qu'ils lisent. Les auteurs devraient comprendre la politique d'évaluation par des pairs afin d'apprécier à sa juste valeur le processus décisionnel de la rédaction et d'ainsi améliorer leurs manuscrits avant de les soumettre. Les principes de l'évaluation par des pairs au sein d'une revue se doivent d'être justes, rigoureux et transparents. A cette fin, une revue doit établir et publier ses propres directives et procédures, y compris des mises à jour régulières. ${ }^{3}$ Cet éditorial explique le processus et les directives actuels de l'évaluation par 
des pairs du Journal et souligne plusieurs améliorations récentes. La politique d'évaluation par des pairs ne représente qu'un aspect des directives éditoriales d'un journal, plusieurs desquelles dépassent la visée de cet éditorial.

\section{Sélection des manuscrits}

Pour chaque soumission, on vérifie d'abord sa lettre d'accompagnement signée par tous les auteurs ; celleci doit indiquer que le contenu est original, qu'il n'a pas été publié auparavant, en partie ou en entier, et que le manuscrit n'a pas été soumis pour être publié dans une autre revue. L'importance de la lettre d'accompagnement a récemment été soulignée. ${ }^{4}$ Chaque manuscrit soumis électroniquement est ensuite converti en fichier PDF, et les auteurs sont priés de vérifier que le contenu (texte, illustrations, tableaux) est complet et précis tel que soumis. Ceci se fait avant que le manuscrit n'entre dans le système d'évaluation par des pairs du Journal. Étant donné les récentes directives générales du ICMJE sur l'enregistrement obligatoire des études randomisées et contrôlées, ${ }^{5}$ nous encourageons désormais l'enregistrement des protocoles dans un registre public reconnu pour tous les tests cliniques de phase 3 (ceux qui évaluent l'efficacité clinique ou les effets indésirables), ainsi que le numéro d'enregistrement de l'étude sur le manuscrit. Bien que l'enregistrement du protocole soit encouragé, le Journal n'exige pas encore un tel enregistrement comme condition de publication.

Lors de la prochaine étape de traitement du manuscrit, le rédacteur en chef ou le rédacteur adjoint vérifie que chaque manuscrit a reçu l'approbation d'un comité d'éthique et évalue la conformité du manuscrit avec les exigences de contenu et de format telles que décrites dans les Instructions aux Auteurs publiées dans les numéros de janvier et de juillet et disponibles sous http://www.cja-jca.org. La priorité est ensuite donnée aux manuscrits satisfaisant ces conditions pour une potentielle évaluation par des pairs. La hiérarchisation des manuscrits est devenue nécessaire, étant donné que le Journal Canadien d'Anesthésie, comme nombre d'autres revues, fait face à un volume croissant de soumissions ces dernières années, tout en n'ayant à sa disposition qu'une équipe limitée d'experts à même d'entreprendre l'évaluation. Les manuscrits mal écrits ainsi que ceux présentant des faiblesses méthodologiques ou des résultats mal présentés ont peu de chance d'être sélectionnés pour une évaluation par des pairs. Les manuscrits à évaluer sont répartis dans les catégories suivantes: 1) comptes-rendus d'études originales ; 2) articles de synthèse (longs ou courts) ; 3) présentations de cas / séries de cas ; et 4) articles spéciaux. Chaque manuscrit est attribué à deux évaluateurs.

\section{Sélection des évaluateurs}

Les comptes-rendus d'études originales sont habituellement attribués à un membre du comité de rédaction et à un évaluateur invité. Pour chaque manuscrit, ces personnes sont sélectionnées au sein d'un des 17 départements universitaires d'anesthésiologie canadiens ou d'institutions internationales, et sont choisies en fonction de leur expertise en méthodologie de recherche et dans le domaine de la soumission. Bien que le comité de rédaction et les évaluateurs invités soient en général choisis par les rédacteurs, nous invitons occasionnellement des évaluateurs nommés par les auteurs si le domaine est très spécialisé et que le nombre d'experts est limité. Bien que les recommandations d'évaluateurs nommés par les auteurs puissent être biaisées en faveur de l'acceptation du manuscrit, la qualité des évaluations d'un évaluateur nommé par un auteur, telle que vérifiée par un Instrument de Qualité de Révision, ${ }^{6}$ ne diffère en rien des exigences pour les évaluateurs sélectionnés par la rédaction. Lorsque des évaluateurs externes sont invités à entreprendre une évaluation, il leur est d'abord demandé de déclarer tout conflit d'intérêt avant de recevoir un fichier PDF du manuscrit. Pour la soumission des manuscrits et l'évaluation par les pairs, le Journal a fait la transition du support papier à un processus informatisé en 2005 ; des instructions pour compléter les évaluations ainsi qu'un formulaire d'évaluation électronique accompagnent en pièces jointes le fichier du manuscrit transmis par courrier électronique. Nous exigeons que les évaluateurs complètent et renvoient leurs évaluations dans un délai de trois semaines.

La possibilité de pouvoir demander des crédits d'éducation médicale continue (EMC) dans le programme de maintien des compétences du Collège Royal des Médecins et Chirurgiens du Canada est maintenant offerte à nos évaluateurs canadiens invités à titre incitatif. Afin de faciliter ce procédé, des instructions quant à la documentation des heures pouvant être créditées en relation avec une évaluation sont également jointes au formulaire de l'évaluateur. La communication via courrier électronique avec tous les évaluateurs facilite le bon fonctionnement des évaluations; ceci fait partie de notre effort continu pour diminuer le temps d'attente lié au processus d'évaluation par des pairs (la période allant d'une soumission originale à la décision). Le temps d'attente moyen du Journal pour les évaluations par des pairs est actuellement inférieur à six semaines. Des périodes d'évaluation plus longues peuvent survenir lors 
d'évaluations tardives ou à cause de la complexité inhabituelle d'un manuscrit.

\section{Évaluation 'à l'avengle'}

Comme cela est le cas dans la majorité des revues de la spécialité, les évaluations de manuscrit sont effectuées à simple insu en ce que les évaluateurs connaissent le nom des auteurs ainsi que leurs affiliations, mais que les copies des "Commentaires destinés aux auteurs » joints à la lettre de décision sont anonymes. Sur un autre formulaire intitulé "Commentaires au comité », qui n'est pas envoyé aux auteurs, les réviseurs complètent une liste de vérification et font des recommandations au comité quant à l'acceptation ou l'acceptation conditionnelle à des modifications appropriées. Il y a quelques années, le Journal a tenté de minimiser les biais des évaluateurs en utilisant un système d'évaluation à double insu, système qui excluait les noms et affiliations des auteurs des manuscrits envoyés pour évaluation. Toutefois, ce processus a été abandonné, certains auteurs étant facilement identifiables, soit en se citant eux-mêmes, ou en faisant le compte-rendu de certaines études et expériences uniques à un centre ou un laboratoire donné.

Le fait de ne pas communiquer l'identité des auteurs aux évaluateurs pourrait nuire à la qualité de l'évaluation ou des recommandations en ce qui concerne la publication. ${ }^{7} \mathrm{C}^{\prime}$ est pour cette raison que certaines revues d'anesthésie, comme par exemple le journal en ligne BMC Anesthesiology (www.biomedcentral.com), utilisent un système " ouvert » d'évaluation par les pairs : les lecteurs ont accès à « l'histoire prépublication » de chaque manuscrit publié, y compris aux critiques des évaluateurs identifiés et aux réponses des auteurs. Ce processus d'évaluation est "ouvert ", néanmoins les évaluateurs pourraient être moins critiques en commentant le travail de leurs collègues. En outre, une étude récente comparant des modèles d'évaluation ouverts et à simple insu suggère que l'évaluation par des pairs "ouverte » pourrait inciter certains experts à refuser d'évaluer des manuscrits. ${ }^{8}$ Étant donné que l'un des grands défis de tout système d'évaluation par des pairs est de maintenir une équipe d'évaluateurs experts enthousiastes, nous continuerons pour l'instant de suivre la tradition d'un système d'évaluation par les pairs à simple insu.

\section{La décision}

Quand les évaluations du membre du comité éditorial et de l'évaluateur invité reviennent au bureau de rédaction, le rédacteur en chef ou le rédacteur adjoint (en particulier si le rédacteur en chef a un conflit d'intérêt par rapport à un article donné) révise le dossier complet et prend une décision finale quant à l'acceptation. Les manuscrits identifiés par le processus comme présentant une originalité suffisante, une validité scientifique ainsi qu'une importance globale tout en répondant aux normes éthiques ${ }^{9}$ seront très probablement acceptés. Lors de l'évaluation des comptes-rendus d'études randomisées et contrôlées ou de recherche de science de base, nous admettons qu'il n'existe pas "d'étude parfaite ", aussi l'importance de la question primaire est évaluée avec précaution et ce, en conjonction avec la rigueur du devis expérimental et la qualité scientifique du compte-rendu. Les articles de synthèse et les comptes-rendus de cas/séries de cas doivent présenter une valeur éducative, une innovation adéquate, et refléter l'état actuel de la connaissance d'un sujet en particulier.

Durant le processus de révision, des questions complexes quant à la méthodologie, aux statistiques ou à l'éthique peuvent se présenter. Lorsque ces questions dépassent le domaine d'expertise de l'évaluateur ou du rédacteur en chef, nous faisons appel au consultant en éthique du Journal, au consultant épidémiologiste ou à un statisticien invité. Ces opinions supplémentaires d'experts ont également leur poids dans la décision finale concernant l'acceptation, et les commentaires supplémentaires sont transmis aux auteurs.

Très peu $(<3 \%)$ de manuscrits sont acceptés sans modifications, et l'acceptation finale dépend en général de la réception de corrections appropriées en réponse aux commentaires des évaluateurs et de la rédaction. Le Journal ne se fixe pas un objectif de taux d'acceptation, et le taux d'acceptation actuel (28\% en 2005) varie d'une année à l'autre en fonction des manuscrits reçus. Lorsque les corrections exigées sont mineures et que les auteurs ont répondu de façon adéquate, la décision d'acceptation est prise par le rédacteur en chef sans renvoyer le manuscrit pour réévaluation. Toutefois, lorsque les corrections exigées sont importantes, une décision d'acceptation potentielle ne sera prise qu'après réévaluation du manuscrit corrigé ; ceci peut impliquer une réévaluation additionnelle par les pairs, en général par les mêmes évaluateurs ayant critiqué la version originale. Ceci est particulièrement le cas lorsqu'il n'est pas clair si les problèmes sont liés à des faiblesses dans le compterendu ou des faiblesses méthodologiques. Alors que des faiblesses dans le compte-rendu sont corrigeables, des faiblesses de méthodologie ne le sont en général pas. C'est pourquoi il est possible que les auteurs soient informés que nous sommes dans l'impossibilité de prendre une décision avant une nouvelle soumission et une réévaluation. 


\section{Éditoriaux}

Le Journal publie en moyenne deux éditoriaux par numéro, et un sondage récent auprès du lectorat indique leur popularité. Durant le processus d'évaluation, les évaluateurs sont invités à recommander les manuscrits pouvant potentiellement justifier un éditorial ; ils peuvent également en suggérer l'éditorialiste. Les éditoriaux sont publiés sous l'invitation du rédacteur en chef. La plupart des éditoriaux sont en rapport avec un article dans un numéro donné et offrent une tribune pour prolonger le contexte de l'article et ce, en puisant dans la littérature pertinente et en émettant des opinions expertes personnelles. Des éditoriaux indépendants sont également publiés ; ils ont pour thème des questions d'éthique, de méthodologie et de compte-rendu d'études, ou traitent de la politique du Journal. Les éditoriaux sont évalués par le rédacteur en chef et sont publiés avec le nom des auteurs, les affiliations et les déclarations de conflits d'intérêts. Les éditoriaux ne reflètent pas la politique du propriétaire du Journal, la Société canadienne des anesthésiologistes.

\section{Lettres à la rédaction}

Nous recevons les soumissions en attente d'une acceptation de publication sous notre rubrique Correspondance. Comme c'est le cas pour les autres manuscrits, les lettres au rédacteur en chef doivent présenter un contenu original qui n'a pas encore été publié et qui n'a pas été soumis pour être publié ailleurs. $\mathrm{Le}(\mathrm{s})$ rédacteur(s) décide(nt) quelles lettres sont publiées en consultant le comité de rédaction au besoin. Toutes les lettres peuvent être remaniées et abrégées. Étant donné que les lettres à la rédaction jouent un rôle important dans l' "évaluation par les pairs post-publication », nous invitons les auteurs d'articles publiés précédemment à répondre aux lettres concernant leurs travaux. De telles réponses, si elles sont acceptées, sont publiées avec la lettre originale.

\section{Politique de langue concernant l'évaluation par les pairs}

En écho à la politique officielle canadienne sur le bilinguisme, les manuscrits peuvent être soumis au Journal en français ou en anglais. Nombre d'auteurs francophones choisissent d'écrire en anglais afin que les résultats de leurs recherches soient plus aisément accessibles à des lecteurs potentiels. L'anglais est devenu la langue de communication scientifique par excellence, et pour cette raison plusieurs auteurs la préfèrent à leur langue maternelle. Toutefois, des résumés en anglais sont disponibles dans le Journal ainsi que dans les bases de données les plus courantes, comme PubMed, Medline et Embase ; ainsi, le contenu d'un article en français ne passe habituellement pas inaperçu. Aussi, les auteurs peuvent soumettre des manuscrits en français, particulièrement s'ils sentent que le message sera mieux transmis s'il est écrit dans cette langue.

Le processus d'évaluation est le même qu'il s'agisse de manuscrits français ou anglais, et les mêmes exigences d'originalité et de validité sont posées. En particulier, le Journal n'acceptera normalement pas une étude qui répète le propos d'une autre précédemment publiée en anglais simplement parce que le manuscrit est écrit dans une autre langue. La proportion des soumissions acceptées tend à être la même dans les deux langues. Les auteurs anglophones aussi bien que francophones sont encouragés à fournir une traduction de leur résumé dans l'autre langue s'ils s'y sentent suffisamment à l'aise. Le Journal fournit une traduction français-anglais ou anglais-français pour ceux qui ne peuvent ou préfêrent ne pas soumettre une traduction. La traduction de résumés du français vers l'anglais permet à la version anglaise d'apparaître dans les bases de données électroniques. Les versions françaises ne sont pas inclues dans ces bases de données mais sont appréciées par le grand nombre d'abonnés francophones du Journal. Le texte intégral des éditoriaux et certains articles particuliers sont publiés dans les deux langues. Cette politique a été adoptée en raison de l'importance des articles en question.

\section{Déclaration de conflits d'intérêt}

Enfin, lorsqu'il est question de l'intégrité du processus d'évaluation par les pairs, nous reconnaissons le fait que les évaluateurs aussi bien que les rédacteurs puissent présenter des conflits d'intérêt. Les conflits d'intérêt sont « un ensemble de conditions par lequel un jugement professionnel au sujet d'un intérêt primaire (tel que la santé d'un patient ou la validité d'une recherche) peut être influencé par un intérêt secondaire (tel qu'un gain financier) ». ${ }^{10}$ De nombreuses revues publient désormais les conflits d'intérêt des auteurs et des évaluateurs. Alors que des intérêts commerciaux peuvent être évidents dans le processus d'évaluation par des pairs, des conflits d'intérêt de la rédaction peuvent agir à des niveaux plus subtils. Par exemple, un rédacteur peut développer un biais pour ou contre un certain groupe d'auteurs; le travail d'un auteur peut également rivaliser avec le travail d'un rédacteur dans le même domaine. ${ }^{11}$ Tout comme nombre d'autres revues dans la spécialité l'ont récemment fait, le Journal Canadien d'Anesthésie déclare désormais sur le site web du Journal les affiliations et conflits d'intérêt, financiers et non financiers, des 
membres du comité de rédaction et des rédacteurs. Les membres du comité doivent également déclarer les conflits d'intérêts réels ou ressentis pour chaque manuscrit qu'ils évaluent, et le rédacteur en chef s'en remet au rédacteur en chef adjoint lors de décisions concernant tout manuscrit venant de son département universitaire. Nous reconnaissons la nécessité d'une transparence accrue pour toutes les revues, ainsi que le besoin de responsabilité de la rédaction pour les décisions concernant l'acceptation. L'efficacité d'une politique sur cette question majeure nécessite une évaluation plus poussée.

\section{Conclusions}

L'évaluation éditoriale par des pairs est un processus très important qui détermine quels manuscrits sont publiés dans les revues dotées de comité d'évaluation par des pairs, tout en ayant une influence majeure sur la qualité des articles publiés. Alors que la science de l'évaluation par les pairs continue d'évoluer, le processus devrait être transparent et devrait intéresser tous ceux qui contribuent à la littérature médicale et qui la lisent. Les publications scientifiques font progresser la pratique de la médecine. En ce sens, nous sommes heureux de tenir les auteurs et notre lectorat au courant de la politique du Journal sur l'évaluation par les pairs.

\section{References}

1 Burnham JC. The evolution of editorial peer review. JAMA 1990; 263: 1323-9.

2 Jefferson T, Alderson P, Wager E, Davidoff F. Effects of editorial peer review: A systematic review. JAMA 2002; 287: 2784-6.

3 Colaianni LA. Peer review in journals indexed in Index Medicus. JAMA 1994; 272: 156-8.

4 Todd MM. A lesson learned (Letter). Can J Anesth 2005; 52: 770-1.

5 De Angelis C, Drazen JM, Frizelle FA, et al. Clinical trial registration: a statement from the International Committee of Medical Journal Editors. Ann Intern Med 2004; 141: 477-8.

6 van Rooyen S, Black N, Godlee F. Development of the review quality instrument (RQI) for assessing peer reviews of manuscripts. J Clin Epidemiol 1999; 52: 625-9.

7 Justice AC, Cho MK, Winker MA, Berlin JA, Rennie $D$. Does masking author identify improve peer review quality? A randomized controlled trial. PEER Investigators. JAMA 1998; 280: 240-2.

8 van Rooyen S, Godlee F, Evans S, Black N, Smith R. Effect of open peer review on quality of reviews and on reviewers' recommendations: a randomised trial. BMJ 1999; 318: 23-7.
9 Bevan JC, Miller DR. Medical journals and cross-cultural research ethics. Can J Anesth 2005; 52: 1009-16.

10 Thompson DF. Understanding financial conflicts of interest. N Engl J Med 1993; 329: 573-6.

11 Haivas I, Schroter S, Waechter F, Smith R. Editors' declaration of their own conflicts of interests. CMAJ 2004; 171: 475-6. 